\title{
EMBRACING THE VALUES OF COGNITIVE DEVELOPMENT IN HIGHER EDUCATION: PSYCHOLOGICAL THEORY, PEDAGOGICAL PRACTICE, SUBJECTIVE EXPERIENCES
}

\author{
Olga Y. Bogdanova, Elena L. Bogdanova, Lidiya V. Komarovskaya \\ National Research Tomsk State University, Tomsk, Russia \\ E-mail: olga_tomsk@front.ru, elena_tomsk.tsu@qip.ru, uni-tomsk@mail.ru
}

\begin{abstract}
Scientific problem lies within the interdisciplinary domain of cognitive development of a person in education; is focused on the search for psychological foundations of educational technologies aimed at embracing values of cognitive development and negotiating diverse educational values and attitudes of students and teachers. The main thesis of the research is based upon the assumption that phenomenon of cognitive development can be positioned as an educational trend adequate to tendencies of development of psychological knowledge and socio-cultural practices in the process of knowledge society emergence.

Strategic task of elaborating educational technologies advancing values of cognitive development in higher education is of growing relevance for Russian educational psychology as internationalization, new educational standards and trends of socio-cultural development pose diverse challenges for educational theory and practice, for students, teachers and researchers.

Research is focused on developing practice of Russian education and the problem of value-laden self-determination of its participants. Necessity to include the epistemological dimension in the content of cognitive development as complex and multidimensional construct is substantiated. The study demonstrates the ways of employing qualitative research methods, reveals ontological and epistemological attitudes of students and teachers, discusses students' subjective representations of educational process and main epistemological categories, and argues that research on educational practice might at the same time be an embodiment of its transformation.

Research methodology includes a methodological reflection of Russian and international trends in the development of psychological knowledge (system anthropological psychology and anthroepistemology).

Main conclusions suggest that: psychological construct of cognitive development acquires multiple dimensions as contextualized in education; constructive negotiation of educational values and attitudes in pedagogical practice is crucial for further development of pedagogical practice itself and its participants; promoting the values of cognitive development in higher education requires specific technologies and forms of educational interaction.
\end{abstract}

Key words: cognitive development, pedagogical practice, system anthropological psychology, epistemological dimension.

\section{Introduction}

Positioning higher education as a sociocultural practice of human resources development defines new focus of scientific interest and statement of research questions open for interdisciplinary discussion. What are the imperatives of rethinking value foundations of organization and outcomes 
of educational practices of a new type? How to embed the trends of development of sociocultural practices and psychological knowledge about the nature of human development into the content of Volume 3, 2012 emerging educational practices? Is value and meaning rebuilding of educational and professional beliefs of these practices' participants possible? What psychological constructs will make it possible to adequately describe emerging educational reality accounting for its complexity, multidimensionality and dynamics? The nature of these questions and search for answers determine the research logic and focus of reflection upon its implementation, researchers' roles and interpretation of results.

The research is aimed at revealing and critical discussion of contradictions characteristic of emerging practice of Russian higher education in the process of transition to new educational standards which are oriented towards the values of cognitive development as an educational outcome. Successful implementation of new educational values implies a transition from reproducing pedagogical model to a competence-based one. The possibility of this transition as such is related to the changes in beliefs of educational process participants about the nature of knowledge and cognition: from understanding of knowledge as a static construct and possibility of its "transmission" towards understanding cognition as a process of constructing new knowledge of a reflexive and activity-based nature. As the processes of cognitive development are "triggered" or "blocked" by epistemological beliefs, the research focus is on the search for grounds for an informed answer to the question: How well do concepts of students' and teachers' about main epistemological categories shaped in the course of previous educational and teaching experience meet the values of cognitive development?

Cognitive development of a person as a prerequisite for sustainable human resource development is considered as an educational trend shaping the contents of key educational constructs which would adequately describe emerging educational reality and ensure "sensitivity" of educational practice to tendencies of psychological knowledge development, sociocultural trends of social development and manifestation of subjective experiences of its participants.

Necessity for resolving the problem of manifestation of these subjective experiences as a foundation for evaluating the context and elaborating educational technologies, which would overcome system limitations in the course of transition from reproducing educational model to a competencebased, determined the choice of research methods and statement of hypothesis. It is hypothesized that embedding qualitative research methods as special kinds of educational tasks and activities in pedagogical practice allows for reconstructing emerging educational reality as a space of manifestation and development of diverse educational values and attitudes of students and teachers.

Methodological reflection of ideas of system anthropological psychology (Клочко, 2005; Клочко \& Галажинский, 2009) and current tendencies of cognitive research in education defines the use of qualitative research methods and character of results interpretation. Discussion of results can become the ground for the retrospective analysis of individual pedagogical practices, definition of limitations and requirements for development of these practices accounting for specific features of national systems of education.

Accomplished research is relevant to the theory and practice of Russian education as it acknowledges the new field of interdisciplinary research significant for revealing contradictions and educational gaps of emerging pedagogical practice. Research results provide grounds for elaboration of adequate educational technologies. The novelty of research for Russian educational psychology is determined by the statement of the research problem and searching for the ways of ensuring "epistemological shift" (Paavola \& Hakkarainen, 2005) in educational beliefs of teachers and students. Relevance of research problem is supported by the perspective of cross-cultural research on cognitive development in education and developing educational practices at the time of higher education internationalization.

\section{Problem of Research}

The core of research problem arises from the contradictions between: 1) the focus of Russian educational practice on the development of cognitive resources of a person as an educational outcome that is normatively stated in new educational standards and lack in applicable educational technologies; 2) elaborated theoretical grounds that enable conceptualization of construct "cognitive development" as multidimensional and including epistemological dimension and underrepresentation of "personal 
epistemologies" (Hofer, 2006) in educational practice. Overview of vast body of research in the field of cognitive development allows for drafting the context of considering cognitive development as an educational construct: 1) studies on the phenomena of cognitive development go beyond the subject-specific domain of cognitive psychology in the field of sociocultural and epistemological practices (Gauvain, Beebem, \& Zhao, 2011; Kasavin, 2009; Niessen, Abma, Widdershoven, van der Vleuten, \& Akkerman, 2008; Olson \& Dweck, 2008; Paavola \& Hakkarainen, 2005; Reed \& Alexander, 2009); 2) acknowledgement of human cognitive resource as a new resource of social development leads to positioning of cognitive development as a cornerstone educational construct that represents trends of socio-economic development and ensures their embodiment in educational practice (Barone \& Werfhorst, 2011; Rindermann \& Thompson, 2011); 3) tendency towards complexity growth of conceptual notions about phenomena of cognitive development in research field and growth of differentiation of subject field of cognitive development (Billing, 2007; Cosmelli \& Ibáñez, 2008; Kornilova, Kornilov \& Chumakova, 2009; Leutwyler, 2009; Sternberg, Grigorenko \& Zhang, 2008; Корнилов \& Григоренко, 2010; Корнилова \& Новикова, 2011); recognition of methodological limitations of the use of quantitative methods for construction of interdisciplinary knowledge about phenomena of cognitive development (Greene, 2012; Koro-Ljungberg \& Barko, 2012; Richardson, 2004; Wheeldon, 2010; Wiliam, 2008); 5) establishment of applied research direction in the field of human resource development and management with emphasis on cognitive features determining professional achievements and innovative potential (Billet, 2009; McCarthy \& Garavan, 2008; Murphy \& Dweck, 2010); 6) shift in educational research on cognitive development to its metacognitive aspects as predictors of a certain quality of cognitive development (Hofer \& Sinatra, 2009; Veenman, Van Hout-Wolters \& Afflerbach, 2006; Vrugt \& Oort, 2008).

Abovementioned tendencies of exploring the phenomena of human cognitive development make it possible to reveal conceptual grounds for building this construct as an educational one and discover the limitations and resources of the development of the emerging practice of Russian education.

Evidence in interdisciplinary research of complexity and multidimensionality of phenomena of cognitive development is not explicitly reproduced in Russian educational standards. Content of general cultural competences is defined through specific kinds of activities which success is determined by the level of certain cognitive skills.

Inherent risks of reduction of cognitive development to acquisition of basic cognitive skills might significantly hinder achievement of required educational outcomes and development of educational practice. Taking into consideration relevant tendencies of exploring the problem of cognitive development would enable education practitioners to properly pose and resolve educational tasks and define psychological foundations for elaboration of appropriate educational technologies maintaining these values.

Inclusion of epistemological dimension in the construct "cognitive development" opens new opportunities for revelation and evaluation of dynamics of value-meaning attitudes of education process participants, formulation of boundary conditions for posing developmental educational tasks and definition of success criteria of their solution.

Significance of accounting for epistemological dimension is justified by the findings of previous research with the modified questionnaire by C. W. Dweck (Nussbaum \& Dweck, 2008; Богданова $\&$ Богданова, 2011a; Корнилова, Смирнов, Чумакова, Корнилов \& Новотоцкая-Власова, 2008). Research results demonstrated that $25 \%-40 \%$ of students depending on the sample accept incremental theory of intelligence (share the values of cognitive development). As different from the results of foreign studies, correlation between the degree of acceptance of incremental theory of intelligence and orientation on educational outcome as cognitive development has not been established in any of student samples. Consequently, even those students who share incremental theory of intelligence and are in principle focused on cognitive development do not regard educational environment as a possible condition for this development. This provides grounds for discussion of epistemological dissonance of educational environment as an essential constraint on realization of developmental potential of educational practice. Utilization of quantitative methods in exploration of epistemological dimension of pedagogical allows revealing contradictions built in this practice, but does not allow representing and 'employing' epistemological beliefs of practice participants.

Thus, the possibility of building educational construct 'cognitive development' on three levels 
of psychological theory, pedagogical practice and subjective experience is linked to the necessity of revealing value-meaning attitudes of participants of educational practice as foundations for elaboraVolume 3, 2012 tion of educational technologies providing for constructive negotiation of these attitudes and their development. Exploration of onto-epistemological beliefs of teachers and students, representation of students' subjective concepts about the educational process, crucial constructs of emerging educational practice and fundamental epistemological categories contextualize this research as a meaningful effort towards embracing and advancing the values of cognitive development in practice of Russian higher education.

\section{The Researchers'Role}

Diversity of methodological approaches to pedagogical practice as sociocultural practice of human resource development makes it necessary to make conscious and informed choice of theoretical grounds for research organization and data interpretation. Quality of research in education is a relevant theme of discussions in the professional community. Researches pose questions related to the use of quantitative, qualitative or mixed methods and rationales of their complementarity (Wheeldon, 2010; Wiliam, 2008; Улановский, 2006), critically reflect upon the tendency to simplify offered solutions for relevant problems of educational theory and practice (Koro-Ljungberg \& Barko, 2012).

Peculiarities of researchers' role in this study consist in the simultaneous retention of dual position of a teacher and a researcher. Understanding of the researchers' role is in line with the view of education research as "a process of representing educational processes, and the representations are never right or wrong, merely more or less appropriate for a particular purpose, and it is perfectly fair to expect the researcher to defend the appropriateness of the representations" (Wiliam, 2008, p. 436). This research stance coheres with methodological foundations of research (system anthropological psychology, anthroepistemology and constructivism) and the nature of explored educational phenomena (onto-epistemological beliefs, subjective representations of educational practice).

It deserves a special emphasis that the researchers' role in the current study was to create favorable environment for 'hearing' and 'listening to' "epistemic voices" (Fuller, 1999) of the participants of pedagogical practice. In this context research practice might be interpreted as an effort to mitigate in qualitative research such facets of "Othering" (Krumer-Nevo \& Sidi, 2012) as: 1) objectification leading to overlooking individual differences and stereotypical perception; 2) decontextualization excluding contextual determinants of behavior; 3) dehistorization emphasizing present time and ignoring previous experience; 4) deauthorization rejecting authorship and interpretation in texts describing research.

Enacted research position is aimed not at receiving exhaustive and straightforward answers to the posed questions and 'completing' research, but at negotiating answers as "epistemological openings to the structures that shape and produce knowledge claims" and "transitions between our epistemological past, our present traditions of thought, and the futurity of the Derridian to come in science, philosophy, and society" (Koro-Ljungberg \& Barko, 2012, p.261).

\section{Theoretical Perspective}

System anthropological psychology (SAP) is proposed as a theoretical ground for exploring cognitive development in education. Relevance of SAP is sustained as it provides conceptual framework for methodological reflection of tendencies of psychological science development from standpoints of post-non-classical psychology and development of a person as a unique, open, self-organizing and self-developing system (Клочко, 2005; Клочко \& Галажинский, 2009). Within the scope of SAP logic of multidimensionality is a tool of professional psychological thinking (Klochko, 2010).

Psychological knowledge constructed based on SAP is considered as a resource for proper description of emerging pedagogical practice and operationalization of dynamic, complex and multidimensional educational constructs. Empirical ground of psychological knowledge (knowledge about human basic cognitive functions) in the logic of multidimensionality is enriched with knowledge about value-meaning attitude of a person towards the process of his/her cognitive development as a requirement for interaction with environment. Basic propositions of SAP essential for searching 
for solution of the problem of embracing the values of cognitive development in education are as follows: 1) emergence of a person's multidimensional world occurs as a result of integration of objective and subjective dimensions; 2) logical growth of system's complexity in the process of its selective interaction with environment through detection of correspondence as a prerequisite for this interaction is a mechanism of a person's development as an open self-developing system.

Ideas drawn from SAP and logic of multidimensionality can be implemented in research on onto-epistemological dimension of pedagogical practice: implicit multidimensionality of educational reality is expressed through individual representations made explicit. Knowledge about onto-epistemological beliefs of participants of pedagogical practice serves as foundation for implementing the idea of selectivity and correspondence as a trigger of cognitive development through elaboration of viable educational technologies (Bogdanova, 2011).

Reference to anthroepistemology, that brings together anthropology and cognitivism in the context of cognitive development, offers a meta-level of reflection of cognitive activity grasping the general principles of human epistemological practices and value underpinnings of knowledge construction (Maffie, 1999; SuáRez, 1999) and insight into personal significance of epistemological practices (Fuller, 1999).

Addressing constructivism as a "new type of cognition claiming for transformative function" (Farman, 2008, p. 34) is inherent in research and reflects the new status of pedagogical practice and its sociocultural functions.

\section{Methodology of Research}

Methods of research include the following: free association, cognitive map construction, the four-quadrant scale developed by Schraw and Olafson (2008) and its adapted version for students. These methods have been employed in previous studies on samples of students (total of 342 people) from large universities in Western Siberia (Russia). Retrospective analysis of research organization and data interpretation have contributed to the adaptation of these methods to the realities of pedagogical practice and led to employing these methods as specific kinds of educational tasks and activities.

The method of free association aims to reveal value-meaning attitudes of students towards basic epistemological categories 'knowledge' and 'cognition'.

Method of cognitive map construction is appropriate to research objectives as it demonstrates hidden cognitive schemes and formations through the analysis of their textual and graphic representations; involves cognitive as well as metacognitive activities result of which can be used for evaluating dynamics of subjective notions and experience of students related to pedagogical practice.

Typology of cognitive maps was used to analyze student's cognitive maps. The task was to represent students' ideas about the educational process. Six types of maps were distinguished in the previous study (Богданова \& Богданова, 2011b). The first type is characterized by diverse images of objects (drawing, plot picture, symbolic representation). The second type shows graphic representations of educational process including axis of time dimension with variations of a dependent variable (achievement, efficiency, activity, knowledge acquisition, skills, test and final test). Maps which show enumeration of structural elements of educational process with indications of links between them and authorship of graphic representation (explicit or implicit modality) belong to the third type. The fourth type includes maps showing hierarchy of structural elements of educational process and their interrelation. Maps representing educational process in the form of conceptual maps (concepts, meaningful links between them, hierarchy, feedback loops (Eden, 2004)) were considered as belonging to the fifth type. Criteria of cognitive complexity such as number of structural elements and the links between them, openness and dynamics can be applicable for this type of map. The sixth type of maps included maps which had features of different types (mixed type).

The four-quadrant scale (Schraw \& Olafson, 2008) was used as a tool for assessing teachers' epistemological and ontological worldviews which define individual styles of professional thinking, preference for traditional or constructivism based pedagogical practices and quality of educational outcomes. Constructivist approach to competence-based education mitigates reduction of educational outcome to its pragmatic constituent not accounting for value-meaning and motivational constituents. 
The four-quadrant scale, developed by Schraw and Olafson (2008), is a measurement instrument consisting of the two axes which intersect and form the four quadrants. These quadrants represent difVolume 3, 2012 ferent epistemological and ontological beliefs. The handout with the scale includes brief descriptions and educational implications of key terms used in the scale such as ontology as "the study of beliefs about the nature of reality" and epistemology as "the study of what can be counted as knowledge, where knowledge is located, and how knowledge increases" (Schraw \& Olafson, 2008, p. 33).

Based on these two dimensions four descriptions of personal beliefs are introduced and might be summarized as follows: 1) epistemological realist (fact-based subject matter, a fixed body of knowledge and basic skills that need to be acquired and mastered);2) epistemological relativist (everchanging knowledge, student-centered curriculum, problem based teaching); 3) ontological realist (one and the same type of teaching for every learner, focus on individual work, teacher defines the activities to be done); 4) ontological relativist (diversity of realities; teacher as facilitator of learning; group work of students). The task is to read the instructions for the scale, mark the position on it and write an explanation of the choice. The choice of position reflects the individual teacher experience and beliefs about the process of learning and teaching practices.

Adapted version of the four-quadrant scale for students was used to reveal their ontological and epistemological attitudes and preferences towards organization of pedagogical practice. The task was to read brief explanations of epistemology and ontology, as well as descriptions of ontological and epistemological worldviews characteristic of four quadrants, indicate by a sign their self-ratings within one quarter and provide detailed argumentation of the choice.

\section{Sample of Research}

Participants of research were 57 students majoring in Psychology; 16 university teachers who had diverse teaching experience and 17 postgraduate students enrolled in a program for teacher training at a large university in Western Siberia (Russia).

\section{Ethical Considerations}

Employment of research methods as embedded in pedagogical practice diagnostic tools mitigates artificial mode and tensions characteristic of research organization in education. Work with the methods has been accomplished as a kind of educational activity logically coherent with the content of two graduate courses taught for students majoring in Psychology. It is important that qualitative methods of research performed not only diagnostic function, but also developmental. The process and results of working with the research tools have become the subjects of reflexive discussions and have been reformulated in the topics for students' individual and group research projects and essays.

The four-quadrant scale for teachers (Schraw \& Olafson, 2008) has been employed during programs for continuing professional development and teacher training. Reflexive discussions within professional community have been preceded with the anonymous completion of the four-quadrant scale.

Prior to introducing the research methods as educational tasks and activities it was clearly stated that results will be used anonymously for research purposes, become themes for classroom discussions and will not have any impact on course grades.

\section{Data Analysis}

Words 'knowledge' and 'cognition' were used as stimuli for a simplified version of free associations method. Associations occurring most frequently and important for research logic for the word 'knowledge' are as follows: information (40), power (38), light (29), book (25), teacher (24), university (20), cognition (17), learning (15), experience (13), awareness (12) and authority (11). Associations with the word 'cognition' include: studying information (36), acquisition of information (34), experience (30), acquisition of knowledge (24), getting to know something new (24), learning (22), discovery (14), development (12), and depth (11).

As a result of accomplishing the task of graphically representing students' conceptions about 
educational process at university the following data according to typology of cognitive maps was obtained: type $1-19$ maps; type $2-13$ maps; type $3-7$ maps; type $4-5$ maps; type $5-3$ maps; mixed type -6 maps; 4 students did not complete the task.

Analysis of data for adapted version of the four-quadrant scale for students showed the following distribution of preferences for quadrants: a) ontological relativist - epistemological relativist (constructivist model of education) - 20; b) ontological realist - epistemological realist (reproducing model of education) - 15; c) ontological realist - epistemological relativist - 9; ontological relativist - epistemological realist -5 ; choice of position which does not lie in a quadrant (intersection of axes or on the axis) -8 .

Data for the four-quadrant scale (Schraw \& Olafson, 2008) for teachers and postgraduate students was as follows: a) ontological relativist - epistemological relativist (constructivist model of education) -19 ; b) ontological realist - epistemological realist (reproducing model of education) $-2 ; \mathrm{c}$ ) ontological realist - epistemological relativist -5 ; ontological relativist - epistemological realist -7 ; choice of position which does not lie in a quadrant (intersection of axes or on the axis) - none.

\section{Results of Research}

Analysis of the most frequently occurring associations with the words 'knowledge' and 'cognition' provides grounds for reconstructing students' notions about nature of knowledge and the process of cognition. Associations show: a) tendency to make no difference between knowledge and information; b) non-reflexive attitude towards category 'knowledge' evident through the use of clichés characteristic of the Russian language (power, light); c) object level of perception of the category 'knowledge' (book, university, school). Minor part of students gives associations representing knowledge as dynamic and personally significant construct (movement, discovery, experience). Associations with the word 'cognition' include mostly verbs denoting passive object position in educational process (study, acquire). Along with the dominant attitude towards 'cognition' as information acquisition minor part of students demonstrates orientation to 'cognition' as meaning-making process (discovery, development, meaning, depth, movement, growth, thinking and search).

The conclusion can be drawn that more than $60 \%$ of students share the values of reproducing educational model which are rooted in the previous educational experiences and to a large extent get reinforced in current practices; for a smaller part of students their personal preferences are to a considerable degree in agreement with the values of development in a competence-based education. Conclusions drawn from data analysis are consistent with interpretations of students' cognitive maps as a larger part of students demonstrates object, alienated, functional and simplified perception of the educational process.

Analysis of students' cognitive maps leads to the conclusion that typology of cognitive maps developed on the basis of students' graphic representations can be applied to analysis of cognitive maps obtained in different studies and to a certain degree reflects stages of emergence of a multidimensional world of a person within the framework of SAP: object space, time, meanings and values.

Following conclusions can be drawn from findings based on four-quadrant scale: a) ontoepistemological preferences of a larger part of students and teachers are located in polar quadrants corresponding to reproducing educational model (ontological and epistemological realist) and constructivist model (ontological and epistemological relativist); b) teachers and postgraduate students enrolled in a program of teacher training have certainty in ontological and epistemological attitudes, while some students express uncertainty and choose borderline locations. This difference might be attributed to professional teaching experience, reflexive and self-referential mode of thinking about educational practice. Content analysis of written argumentation for chosen location shows that students preferring constructivist model of education provide more elaborate explanations of their choice. Correspondingly, students supporting the values of reproducing educational model either do not write explanations or confine themselves to impersonal statements of socially accepted norms and established educational traditions. Overall, teachers turn out to be more reserved and categorical in commentaries in comparison with postgraduate students enrolled in a teacher training program. Out of ten teachers' written explanations endorsing constructivist educational model (ontological relativist - epistemological relativist) five explanations correspond by implication to reproducing 
educational model. Four other commentaries showing that teachers partially share the values of constructivist education have explicit indications of accepting the values of reproducing educational model. Meaningful gaps between students' ontological and epistemological preferences and written explanations have not been observed. These findings might evidence that values of development are accepted by some teachers as known or socially desirable in the process of modernization of Russian education while educational values that get endorsed in pedagogical practice and shape its outcomes are rooted in previous professional experience.

Following the logic of research it should be emphasized that a larger part of students on the one hand gives preference to constructivist approach to competence-based education as a condition for their development. On the other hand, students' epistemological attitudes towards knowledge as static and devoid of personal significance construct, and cognition as passive acquisition of prefabricated information products might limit implementation of cognitive development ideas in education. Support of the research hypothesis about diversity of values and attitudes towards organization of pedagogical practice raises the issue of necessity of their constructive negotiation, acknowledges significance of epistemological dimension of cognitive development as an educational construct and relevance of elaborating educational technologies facilitating "epistemological shift" (Paavola \& Hakkarainen, 2005 ) in students' and teachers' attitudes, values and beliefs about pedagogical practice.

\section{Limitations}

Major limitations of current research are rooted in qualitative methodology and related to issues of statistic validity of results and constructs, sample representativeness, potential for research replication and generalization of results.

However, it is important that employment of qualitative methods (free associations, cognitive maps, the four-quadrant scale by Schraw and Olafson (2008)) overcomes such limitations of quantitative methods as: lack of practical implementations of research results; problem of transfer of diagnostic tools (questionnaires) into different contexts of national systems of education; inertia of questionnaires as research tools in the context of sociocultural developmental trends (Richardson, 2004).

Content analysis of explanations as in the four-quadrant scale reveals meaningful gaps in subjective representations and contributes to objectification of research conclusions.

Dependence of results interpretation on values shared by the researcher and his/her research, professional and subject-specific competences might be considered a substantial limitation. However, possibility and relevance of exploring phenomena that are not measurable in terms of quantitative parameters and operationalizing qualitative data as foundations for transformation of social practices (in this case - pedagogical practice) are acknowledged in the process of establishment of constructivist trend in psychological science. Moreover, one of the quality criteria becomes the degree of involvement of a researcher in reality being explored (Улановский, 2006).

It also has a special meaning in the context of current research that limitations related to employment of methods focused on representations of subjective experiences and followed up with reflexive discussions at the same time define perspectives of research participants' development. In this case representations are considered as cognitive phenomena enabling sense-making construction of the world and communication (Potter \& Edwards, 1999).

Overall, limitations inherent in research on new educational constructs following qualitative methodology become the subjects of reflexive thinking of a researcher as well as research participants and can be considered as resources for professional and personal development.

\section{Discussion}

Positioning embracement of cognitive development values in education as their acknowledgement and advancement at the levels of psychological theory, pedagogical practice and subjective experience defines multidimensionality and complexity of this phenomenon as educational construct. Research focus on the epistemological dimension of human cognitive development is linked with the special significance of "personal epistemologies" (Billet, 2009; Hofer, 2006) as triggering the 
process of this development and its quality. Probably, it does make sense to research not only epistemological dimension of cognitive development as educational construct, but also metacognitive (as determining not only efficient usage of available cognitive strategies, but ability to construct subjectively new strategies accounting for individual differences in cognition), sociocultural (the issue of universals in cognitive processes), economic (global trend of commercialization of human cognitive abilities) and other dimensions.

Emphasis on the form of employing qualitative research methods allows positioning these methods as resources of student's cognitive development. During the work with these methods such deficits have been revealed as low level of students' reflection upon process, goals, means and outcomes of educational activities, and as a consequence, inability to represent subjective models of cognition implying identification of structural elements, process characteristics and establishment of correct links between them. At the same time, cognitive map construction can be considered as a developmental educational task aimed at transfer of students' subjective representations of goals, means and outcomes of educational activities in the field of reflection and cognitive development.

Indicated gap between the required and current level of interdisciplinary cognitive research in Russian education makes it feasible to refer to the foreign practice of research in this field which has a long-standing history and vast body of published literature. However, direct transfer of this experience in Russian educational practice seems to be not productive. Interpretation of accumulated experience in the context of national systems of education demands approaching it not from the outside, but from the inside of pedagogical practice. This can be made possible through maintaining the dual position of a teacher and a researcher. The second important issue is that this dual position not only ensures productive integration of theoretical knowledge in pedagogical practice, but also adds coherence and continuity to value and methodological foundations at all the levels of organization of educational interaction. It is suggested that this kind of approach to research is adequate under conditions of developing educational practice as it lets not only to explore educational reality in the process of its emergence, but also contribute to its transformation.

\section{Conclusions}

Introduction of new educational standards in Russia can be viewed as a reflection of the internationalization at the level of a national system of education. At the same time it is a challenge for the educational system as a transition to new foundations of pedagogical practice organization requires relevant psychological knowledge, coherence in values and attitudes. Problem field of cognitive domain as a subject of interdisciplinary research in education is in the state of emergence while research findings indicate the necessity of negotiating diverse educational preferences, attitudes, values and meanings in pedagogical practice. Following the logic of SAP constructiveness of this negotiation could be defined through elaboration of such educational technologies which would be aimed at correspondence and development.

Research findings suggest that the use of qualitative methods as subjectively new means of representing educational reality has potential not only for their usage as diagnostic tools embedded in pedagogical practice, but also for designing developmental educational technologies. Current research might be included in a series of studies implemented by the authors of this article and focused on the phenomenon of cognitive development in education. Research findings contribute to understanding of deep foundations for advancing the values of cognitive development in education and shape future research directions: definition of new educational constructs allowing informative descriptions of emerging educational reality and revealed educational phenomena; elaboration of educational technologies aimed at negotiation and advancement of values of cognitive development in pedagogical practice; cross-cultural research on epistemological dimension of pedagogical practices.

\section{Acknowledgements}

The authors acknowledge genuine interest, meaningful discussions and constructive feedback of research participants on issues raised within the research scope.

This research was supported by grant from the Ministry of Education and Science of the Russian 
Federation within the implementation of Federal goal program "Scientific and scientific-pedagogical 15

faculty of innovative Russia for the period of 2009-2013” (SC P1214).

\section{References}

Barone, C., \& Werfhorst, G. van de Herman. (2011). Education, cognitive skills and earnings in comparative perspective. International Sociology, 26, 483-502. doi: 10.1177/0268580910393045.

Billet, S. (2009). Personal epistemologies, work and learning. Educational Research Review, 4, 210-219. doi: 10.1016/j.edurev.2009.06.001

Billing, D. (2007). Teaching for transfer of core/cognitive skills in higher education: Cognitive skills. Higher Education, 53, 483-516. doi: 10.1007/s10734-005-5628-5.

Bogdanova, O. Y. (2011). Projection of system anthropological ideas into educational practice. In proceedings of the 12 $2^{\text {th }}$ European Congress of Psychology. Istanbul: ECP (European Congress of Psychology), [CD-ROM].

Cosmelli, D., \& Ibáñez, A. (2008). Human cognition in context: On the biologic, cognitive and social reconsideration of meaning as making sense of action. Integrative Psychological and Behavioral Science, 42, 233-244. doi: 10.1007/s12124-008-9060-0.

Eden, C. (2004). Analyzing cognitive maps to help structure issues or problems. European Journal of Operational Research, 159, 673-686. doi: 10.1016/S0377-2217(03)00431-4.

Farman, I. Р. (2008). Конструктивизм в эпистемологии и науках о человеке (материалы “круглого стола”). [Constructivism in epistemology and sciences about person (a round-table discussion)]. Bonpocbl философии, 3, 3-37.

Fuller, S. (1999). Epistemology in your face. History of Human Sciences, 12 (4), 49-55. doi: $10.1177 / 09526959922120478$

Gauvain, M., Beebem, H., \& Zhao, S. (2011). Applying the cultural approach to cognitive development. Journal of Cognition and Development, 12 (2), 121-133. doi: 10.1080/15248372.2011.563481

Greene, J. C. (2012). Engaging critical issues in social inquiry by mixing methods. American Behavioral Scientist, 56 (6), 755-773. doi: 10.1177/0002764211433794.

Hofer, B. K. (2006). Domain specificity of personal epistemology: Resolved questions, persistent issues, new models. International Journal of Educational Research, 45, 85-95. doi: 10.1016/j.ijer.2006.08.006.

Hofer, B. K., \& Sinatra, G. M. (2009). Epistemology, metacognition, and self-regulation: Musings on an emerging field. Metacognition and Learning. Advanced online publication. doi:10/1007/s11409-0099051-7.

Kasavin, I. T. (2009). The idea of interdisciplinary approach in contemporary epistemology. Diogenes, 56, 110-124. doi: 10.1177/0392192109339683.

Klochko, V. E. (2010). Cultural-historical psychology of L. S. Vygotsky: Exploring the logic of multidimensionality. In Yu. P. Zinchenko \& V. F. Petrenko (Eds.), Psychology in Russia: State of the art. Scientific Yearbook (pp. 112-129).

Kornilova, T. V., Kornilov, S. A., \& Chumakova, M. A. (2009). Subjective evaluations of intelligence and academic self-concept predict academic achievement: Evidence from a selective student population. Learning and Individual Differences, 19, 596-608. doi:10.1016/j.lindif.2009.08.001.

Koro-Ljungberg, M., \& Barko, T. (2012). “Answers,” assemblages and qualitative research. Qualitative Inquiry, 18 (3), 256-265. doi:10.1177/1077800411431562.

Krumer-Nevo, M., \& Sidi, M. (2012). Writing against Othering. Qualitative Inquiry, 18 (4), 299-309. doi:10.1177/1077800411433546.

Leutwyler, B. (2009). Metacognitive learning strategies: Differential development patterns in high school. Metacognition and Learning, 4, 111-123. doi: 10.1007/s11409-009-9037-5.

Maffie, J. (1999). Epistemology in the strong sociology of knowledge. History of Human Sciences, 12 (4), 21-40. doi: 10/1177/09526959922120450.

McCarthy, A., \& Garavan, T. N. (2008). Team learning and metacognition: A neglected area of HRD research and practice. Advances in Developing Human Resources, 10 (4), 509-524. doi: 10/1177/1523422308320496. 
Murphy, M. C., \& Dweck, C. S. (2010). A culture of genius: How an organization's lay theory shapes people's cognition, affect, and behavior. Personality and Social Psychology Bulletin, 36, 283-296. doi: 10.1177/0146167209347380.

Niessen, T., Abma, T., Widdershoven, G., van der Vleuten, C., \& Akkerman, S. (2008). Contemporary epistemological research in education. Theory \& Psychology, 18 (1), 27-45. doi: 10.1177/0959354307086921.

Nussbaum, A. D., \& Dweck, C. S. (2008). Defensiveness versus remediation: Self-theories and modes of self-esteem maintenance. Personality and Social Psychology Bulletin, 34, 599-612. doi: $10.1177 / 0146167207312960$.

Olson, K. R., \& Dweck, C. S. (2008). A blueprint for social cognitive development. Perspectives on Psychological Science, 3 (3), 193-202. doi: 10.1111/j1745-6924.2008.00074.x.

Paavola, S., \& Hakkarainen, K. (2005). The knowledge creation metaphor - an emergent epistemological approach to learning. Science \& Education, 14, 535-557. doi: 10.1007/s11191-004-5157-0.

Potter, J., \& Edwards, D. (1999). Social representations and discursive psychology: From cognition to action. Culture Psychology, 5, 447-458. doi: 10.1177/1354067X9954004.

Reed, I., \& Alexander, J. (2009). Social science as reading and performance: A cultural-sociological understanding of epistemology. European Journal of Social Theory, 12, 21-41. doi: 10.1177/1368431008099648.

Richardson, J. T. E. (2004). Methodological issues on questionnaire-based research on student learning in higher education. Educational Psychology Review, 16 (4), 347-358.

Rindermann, H., \& Thompson, J. (2011). Cognitive capitalism: The effects of cognitive ability on wealth, as mediated through scientific achievement and economic freedom. Psychological Science, 22, 754-763. doi: 10.1177/0956797611407207.

Schraw, G. J., \& Olafson, L. J. (2008). Assessing teachers' epistemological and ontological worldviews. In M. S. Khine (Ed.), Knowing, knowledge and beliefs: Epistemological studies across diverse cultures (pp. 25-44). doi: 10.1007/978-1-4020-6596-5_2.

Sternberg, R. J., Grigorenko, E. L., \& Zhang L. F. (2008). Styles of learning and thinking matter in instruction and assessment. Perspectives on Psychological Science, 3 (6), 486-506. doi: 10.1111/j.1745-6924 $.2008 .00095 x$.

SuáRez, M. (1999). Epistemology on the face of the strong sociology of knowledge: A reply to Maffie. History of Human Sciences, 12 (4), 41-48. doi: 10.1177/09526959922120469.

Veenman, M. V. J., Van Hout-Wolters, B., \& Afflerbach, P. (2006). Metacognition and learning: Conceptual and methodological considerations. Metacognition and Learning, 1, 3-14. doi: 10/1007/s11409-0066893-0.

Vrugt, A., \& Oort, F. J. (2008). Metacognition, achievement goals, study strategies and academic achievement: pathways to achievement. Metacognition and Learning, 30, 123-146. doi: 10.1007/s11409-0089022-4.

Wheeldon, J. (2010).Mapping mixed methods research: methods, measures, and meaning. Journal of Mixed Methods Research, 4 (2), 87-102. doi: 10/1177/1558689809358755.

Wiliam, D. (2008). Comments on Bulterman-Bos: What should education research do, and how should it do it? Educational Researcher, 37, 432-438. doi: 10.3102/0013189X08325678.

Богданова, Е. Л., \& Богданова, О. Е. (2011а). Исследование когнитивных и эпистемологических ограничений развития компетентности студентов в инновационной практике высшего образования. [Research on cognitive and epistemological limitations of students' competence development in innovative practice of higher education]. Вестник Томского государственного университета, 345, 165-170.

Богданова, Е. Л., \& Богданова, О. Е. (2011b). Развивающий потенциал метода построения когнитивных карт в условиях образовательной практики высшей школы. [Developmental potential of cognitive maps construction method in higher education practice]. Вестник Томского государственного университета, 353, 161-165.

Клочко, В. Е. (2005). Самоорганизаиия в психологических системах: проблемы становления ментального пространства личности (введение в трансспективный анализ) [Self-organization in psychological systems: Issues of emergence of mental space of a person (introduction into transspective analysis)]. Tomsk State University. 
Клочко, В. Е., \& Галажинский Э. В. (2009). Психология инновациионного поведения. [Psychology of innovative behavior]. Tomsk State University.

Корнилов, С. А., \& Григоренко Е. Л. (2010). Методический комплекс для диагностики академических, творческих и практических способностей [Procedural complex for assessment of academic, creative and practical abilities]. Психологический журнал, 31 (2), 90-103.

Корнилова, Т. В., Смирнов, С. Д., Корнилов, С. А., \& Новотоцкая-Власова Е. В. Kornilova, Т. V., Smirnov, S. D., Chumakova, M. V., Kornilov, S. A., \& Novototskaya-Vlasova, E. V. (2008). Модификация опросников К. Двек в контексте изучения академических достижений студентов [Modification of C. Dweck's questionnaires in the context of students' academic achievement study]. Психологический журнал, 29 (3), 101-109.

Корнилова, Т. В., \& Новикова, М. А. (2011). Самооценка в структуре интеллектуально-личностного потенциала человека [Self-estimate of men's intellectual-personal potential structure]. Психологический журнал, 32 (2), 25-35.

Улановский, А. М. (2006). Качественная методология и конструктивистская ориентация в психологии [Qualitative methodology and constructivist orientation in psychology]. Вопрось философии, 3, 2737.

Advised by Irakli Imedadze, Dimitri Uznadze Georgian Psychological National Society, Georgia

Received: May 06, 2012

Accepted: June 29, 2012

Olga Y. Bogdanova

PhD., Associate Professor, National Research Tomsk State University, Department of Psychology, Subdepartment of General and Pedagogical Psychology , 36 Lenina Avenue, 634050, Tomsk, Russia.

E-mail: olga_tomsk@front.ru Website: http://www.psy.tsu.ru

Elena L. Bogdanova $\quad$ PhD., Associate Professor, National Research Tomsk State University, Department of Psychology, Subdepartment of General and Pedagogical Psychology , 36 Lenina Avenue, 634050, Tomsk, Russia.

E-mail: elena_tomsk.tsu@qip.ru

Lidiya V. Komarovskaya

PhD., Associate Professor, National Research Tomsk State University, Department of Psychology, Subdepartment of General and Pedagogical Psychology , 36 Lenina Avenue, 634050, Tomsk, Russia.

E-mail: uni-tomsk@mail.ru 